\title{
ENVIRONMENTAL ISSUES OF EMERGING PANGAS (Pangasianodon hypophthalmus) FARMING IN BANGLADESH
}

\author{
I. Z. Anka*, M. A. R. Faruk ${ }^{1}$, M. M. Hasan ${ }^{1}$ and M. A. K. Azad ${ }^{2}$ \\ Chittagong Veterinary and Animal Sciences University, Chittagong-4225, Bangladesh
}

\begin{abstract}
Pangas farming is one of the fastest growing types of aquaculture in Bangladesh. A study was conducted to understand environmental issues of emerging pangas farming in Bangladesh. Data were collected through questionnaire interview and focus group discussion (FGD) with pangas farmers. All together 40 farmers were interviewed and 6 FGD sessions were conducted in Muktagacha, Trishal and Valuka Upazila of Mymensingh district. Positive and negative aspects of environmental integrity were compared. Potential environmental impacts of pangas farming were assessed using certain parameters like land use pattern, water quality management and eutrophication, pond waste management, use of chemicals and antibiotics, and escape of fish. It was found that conversion of agricultural land and beels into pangas pond were remarkable which leads to the quick loss of agricultural land that reduces rice production. The unutilized feed portion accumulated in pangas ponds produced huge pond bottom waste and caused water quality deterioration. Eutrophication was found as a common problem along with discharge of highly nutrient rich water in the paddy field. Management of pond bottom waste was found quite poor though it has some good use in vegetable production in the pond dyke. Indiscriminate use of chemicals and antibiotics had an adverse impact on the environment and human health.
\end{abstract}

Key Words: Pangas farming, Environmental issues, Water quality management

\section{INTRODUCTION}

Pangas (Pangasianodon hypophthalmus) has been emerging as an economically very important species to South-East Asian aquaculture. It is particularly important for their fast growth, year round production and high productivity. Originally, $P$. hypophthalmus is a catfish of the Mekong delta being recognized as the most important and largest inland fishery in the world. This species has become as an important aquaculture species in Indonesia, Malaysia, Cambodia, Bangladesh and China (FAO, 2010).

This exotic species which was brought from Thailand in 1989 has been established as a cultured species in Bangladesh as recognized by FAO in 1990. Since it's introduction, private entrepreneurs brought into it as a one of the main aquaculture species being

\footnotetext{
${ }^{1}$ Department of Aquaculture, Bangladesh Agricultural University, Mymensingh-2202, Bangladesh

2 Department of Fisheries, Ministry of Fisheries and Livestock, Government of the People's

Republic of Bangladesh

*Corresponding author (Email: ishratanka@gmail.com)
} 
cultured in higher stocking density. Due to the success of Pangasius aquaculture practices, a large number of private hatcheries have been developed in Bogra and Mymensingh region. Currently, Pangas farming is one of the fastest growing types of aquaculture in Bangladesh. The estimated Pangasius production in Bangladesh was 300,000 MT/year in 2009 whereas the official statistics was very poor. Pangasius catfish farming has been evolved to a shape of commercial enterprise over the last two decades in north-central part of Bangladesh, particularly in Mymensingh area (Ali and Haque, 2011). Farming has started commercially by a private enterprise named Al-Falah Fisheries since 1993 in Bailor union under Trishal Upazila, Mymensingh. Later, particularly in the last decades, Pangasius culture was spreading to an increasing number of districts and has rapidly evolved into an economically significant activity (Haque 2009). This rapid growth has occurred due to its popularity to the pond farmers for possessing hardy characteristics, higher survival rates, fast growth, and ability to survive at high stocking densities. The species has also proven popular among consumers due to its low market value, making it one of the most important cultured species, particularly among the poor in urban areas (World Fish Center, 2011).

There is great a potential for further development of the pangas industry in Bangladesh. The export potentiality of this species is also very high. Initially there was no environmental problem of this fish under culture condition. However, with the rapid expansation and intesification of farming system, the question of sustainability has become a great issue in recent years among different stakeholders. Water quality problem resulting from high stocking density, increased feeding rate and intake of polluted water are increasingly common in pangas farming. The discharge of off-flavored pond water effluent is another activity associated with environmental degradation. Such water pollution and self pollution of farming operation ultimately lead to disease outbreak. In many respects from an environmental standpoint, Bangladeshi producers fail to make the world grade product (Belton et al., 2011).Therefore, in order to develop sustainable pangasius culture the present study was conducted to understand environmental issues such as general pangas farming characteristics, culture practices, duration, land use, water source, stocking management, discharge of water, water quality, water management and use of chemicals of emerging pangas farming in Bangladesh.

\section{MATERIALS AND METHODS}

The study was focused in Bhaluka, Trishal and Muktagacha Upazila under Mymensingh district where pangas farming are clustered. The research has been conducted with commercial pangas farmers involved in the farming to generate income. A number of 40 pangas farmers were the target group of which 10 from Muktagacha, 15 from Trishal and 15 from Valuka. Data was collected through questionnaire survey and participatory rural appraisal (PRA). The questionnaire was focused mainly on general pangas farming characteristics, culture practices, duration, land use, water source, stocking management, discharge of water, water quality, water management and use of chemicals. Participatory approach was used for the entire study. PRA tools such as focus group discussion (FDG) were conducted with pangas framers. Six FGD were conducted to get the important information about the environmental issues from three selected study areas. 


\section{RESULTS AND DISCUSSION}

\section{Land ownership and soil type}

Average $48.89 \%$ farmers cultured pangas in their own land while $24.45 \%$ farmers took leased from others and $26.67 \%$ used both own and leased land for farming (Table 1). However, maximum farmers $(80 \%)$ of Muktagacha used their own land for farming.

Table 1. Land ownership (\%) of pangas farmers

\begin{tabular}{l|c|c|c|c}
\hline \multicolumn{1}{c|}{ Criteria } & $\begin{array}{c}\text { Muktagacha } \\
\mathrm{n}=10\end{array}$ & $\begin{array}{c}\text { Trishal } \\
\mathrm{n}=15\end{array}$ & $\begin{array}{c}\text { Valuka } \\
\mathrm{n}=15\end{array}$ & Mean \pm SD \\
\hline Owned & 80.00 & 40.00 & 26.67 & $48.89 \pm 27.75$ \\
Leased & 20.00 & 26.67 & 26.67 & $24.45 \pm 3.85$ \\
Both & 0.00 & 33.33 & 46.67 & $26.67 \pm 24.04$ \\
\hline
\end{tabular}

Unlike rural pond aquaculture, land ownership did not create any major constraints on the way of the pangas culture. Lands were reported as fertile enough by the farmers. Three types of soil were reported by the pangas farmers. Overall average $60 \%$ farms had clay type soil followed by loam $(44.45 \%)$ and silt $(26.67 \%)$.

\section{Water source}

Most of the farmers were found to use both rain and ground water (68.69\%) (Fig. 1). Fish farms have to be based primarily on access to surface or underground sources of water (Pillay, 1992). In the present study, farmers used deep tube well for pumping ground water and allowed through pipelines into the ponds without any regulations. After more than a decade of pumping there are still no governmental regulations concerning the use of groundwater in pangas farm.

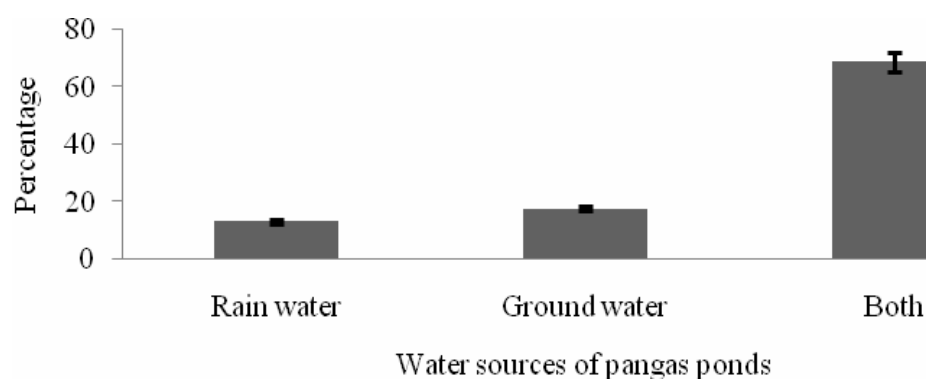

Fig. 1. Water source used in the pangas ponds

\section{Culture strategy}

All farmers prepared their ponds before releasing fry through dyke repairing, weed removal and controlling, mechanical mud removal and liming. Farmers used to collect nursed pangas fingerling of about $50 \mathrm{~g}$ size from generally Adamdighi, Bogra. Farmers mentioned that more benefits, maximum nutrient utilization and good management practices are the major advantages of polyculture system. In this system farmers used pangas as main species. Majority of the farmers (97.78\%) practiced polyculture of pangas 
with carps (Table 2). Ali and Haque (2011) also reported that the farming system of Pangasius in Bangladesh is polyculture with carps. In the present study the average stocking density of pangas polyculture per hectare was 59,238 where pangas was $43,514.49$ (73\%), carp was 12,198.03 (20\%) and tilapia was 3526.429 (7\%). Belton et al. (2011) reported that the vast majority of pangas farms in Bangladesh stock around 10-20\% filter-feeding carps which consume algal blooms produced in the fertile ponds.

Table 2. Stocking density (fry/ha)

\begin{tabular}{l|c|c|c|c}
\hline Criteria & Muktagacha $(\mathrm{n}=10)$ & Trishal $(\mathrm{n}=15)$ & Valuka $(\mathrm{n}=15)$ & Average \\
\hline Pangas & $42482.00 \pm 8454.375$ & $54278.13 \pm 20128.27$ & $33783.33 \pm 9189.634$ & $43514.49 \pm 12590.76$ \\
Carp & $10524.50 \pm 6231.539$ & $3783.273 \pm 1848.88$ & $22286.33 \pm 8293.383$ & $12198.03 \pm 5457.934$ \\
Tilapia & 0.00 & $4320.00 \pm 876.812$ & $6259.286 \pm 1348.272$ & $3526.429 \pm 740.695$ \\
\hline
\end{tabular}

The average production of pangas was recorded 56.32 MT/ha. Edwards and Hossain (2010) also reported the production of pangas as 60-70 MT / ha of 1.0 to $1.2 \mathrm{~kg}$ fish in 10 months by commercial farmers where it was $40 \mathrm{MT} /$ ha by small farms. Only $10 \%$ farmers got training on pangas farming from different sources. Most of the farmers started farming getting experience from other pangas farmers.

\section{Land use trend}

The present study reported the conversion of $75.56 \%$ rice fields and $13.33 \%$ beel areas to pangas ponds (Fig. 2). Ali and Haque (2011) found around 10.1\% of rice field conversion to pangas farms where around $48 \%$ area of dykes were used to produce agricultural crops in Mymensingh district of Bangladesh.

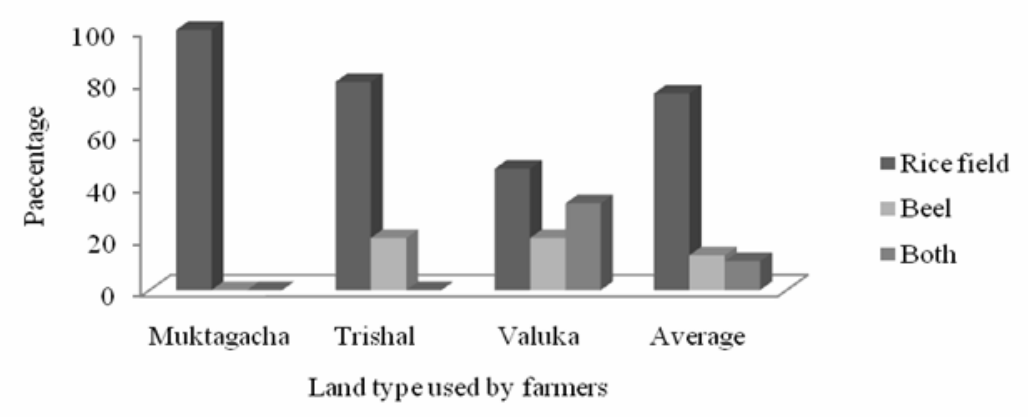

Fig. 2. Type of land used by pangas farmers

From the environmental point of view, the conversion of rice field into farm leads to the quick loss of agricultural land that reduced rice production and destruction of natural habitat and ecosystem (Figs. 3 and 4).

Terrestrial biodiversity could also be reduced due to this conversion. Moreover, due to use of beels as pangas farms, indigenous species in the beels found decreased remarkably. Possible adverse consequences of this conversion into aquaculture are therefore the major impacts those could be addressed as habitat modification or alteration. Goldberg et al. (2001) 
also stated that, habitat conversion attracts attention to natural habitat alteration and destruction and is considered as an important aspect for increasing aquaculture productivity. It was observed from the present study that the surrounding areas of pangas farms may have some ecological effects. It may results process of environmental food web and overall cycle transformation or disruption. Larger beels was found to be exposed on risk of biodiversity loss by reducing indigenous species for pangas farming. In present study there was a drawback that all qualitative data were not available to express the ecological changes.

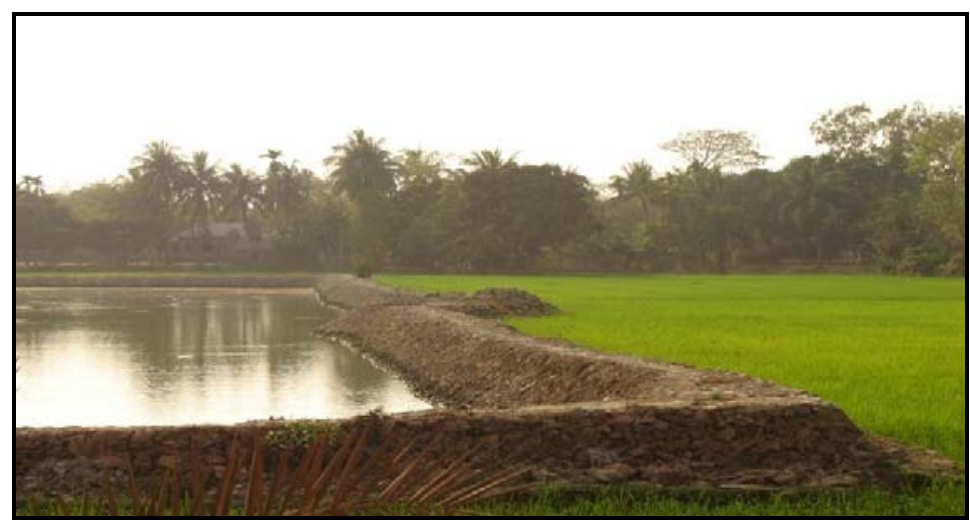

Fig. 3. Conversion of rice field into pangas farm

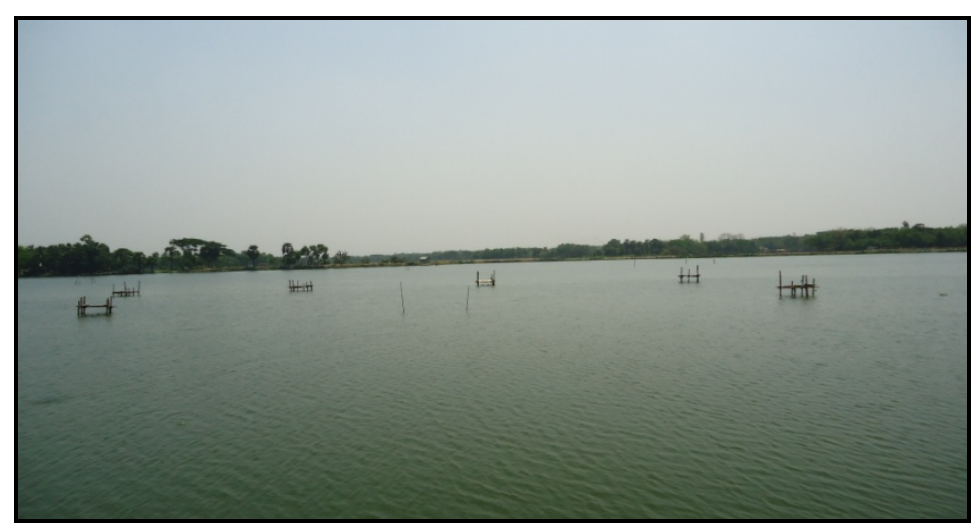

Fig. 4. A huge pangas farm in beel area of Valuka

\section{Farm water management and problems}

Algal bloom was found as a remarkable problem by about $90 \%$ farmers in Trishal. About $68.89 \%$ farmers faced oxygen depletion followed by $67.78 \%$ algal bloom and $63.33 \% \mathrm{pH}$ drop on an average (Fig. 5).

About 46.67 \% farmers in Valuka monthly checked their pond water. Farms of Muktagacha found very reluctant in doing this work. Only $30 \%$ farm at Muktagacha used to check water quality only once a year (Table 3). Farmers were found not aware about water quality management. 


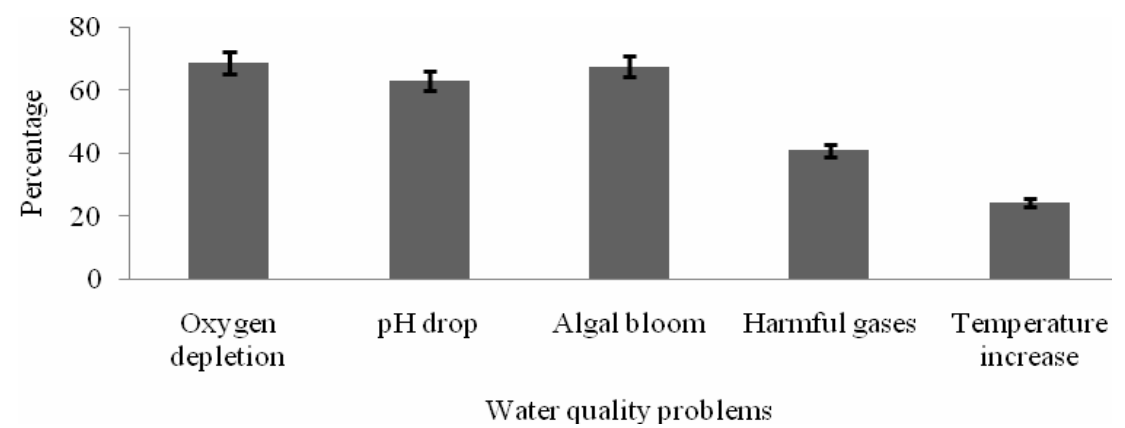

Fig. 5. Types of water quality problems in pangas farms

Table 3. Water quality checking through the farming period

\begin{tabular}{l|c|c|c|c}
\hline \multicolumn{1}{c}{ Criteria } & $\begin{array}{c}\text { Muktagacha (\%) } \\
\mathrm{n}=10\end{array}$ & $\begin{array}{c}\text { Trishal }(\%) \\
\mathrm{n}=15\end{array}$ & $\begin{array}{c}\text { Valuka (\%) } \\
\mathrm{n}=15\end{array}$ & Mean \pm SD (\%) \\
\hline Daily & 0.00 & 0.00 & 6.67 & $2.22 \pm 3.85$ \\
Weekly & 0.00 & 0.00 & 26.67 & $8.89 \pm 15.40$ \\
Biweekly & 0.00 & 6.67 & 20.00 & $8.89 \pm 10.18$ \\
Monthly & 0.00 & 13.33 & 46.67 & $20.00 \pm 24.04$ \\
Yearly & 30.00 & 20.00 & 0.00 & $16.67 \pm 15.28$ \\
\hline
\end{tabular}

The unutilized portion of feeds after decomposition by microorganisms leads to deterioration of pond water quality. Majority of the farmers were reported to apply salt $(42.22 \%)$ and lime $(42.22 \%)$ to solve water quality problem on average. Water quality was also improved through required changing of average $26.67 \%$ water by pangas farmers. In small cases some farmers also found to apply Oxygen promoter (2.22 \%) and Oxy-A (6.67\%) to solve the oxygen deficiency and Geolite $(11.11 \%)$ and horra pulling $(11.11 \%)$ to remove the toxic gases (Fig. 6).

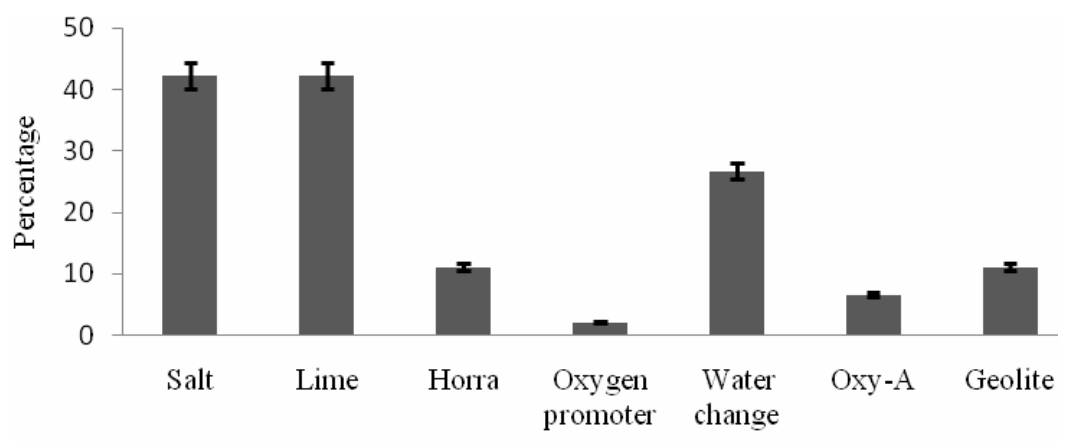

Fig. 6. Measures taken against water quality problems

Water logging sometimes caused outbreak of mosquito and people have to suffer from disease caused by this as all species of mosquito are aquatic breeders. 


\section{Water exchange and discharge}

Regular water change was maintained mostly through two to four times per year by farmers. Maximum average $32.22 \%$ farmers exchanged their pond water two times per year. About $14.44 \%$ farmers did not exchange their pond water at all while $21.11 \%$ farmers performed this activity when needed (Fig. 7).

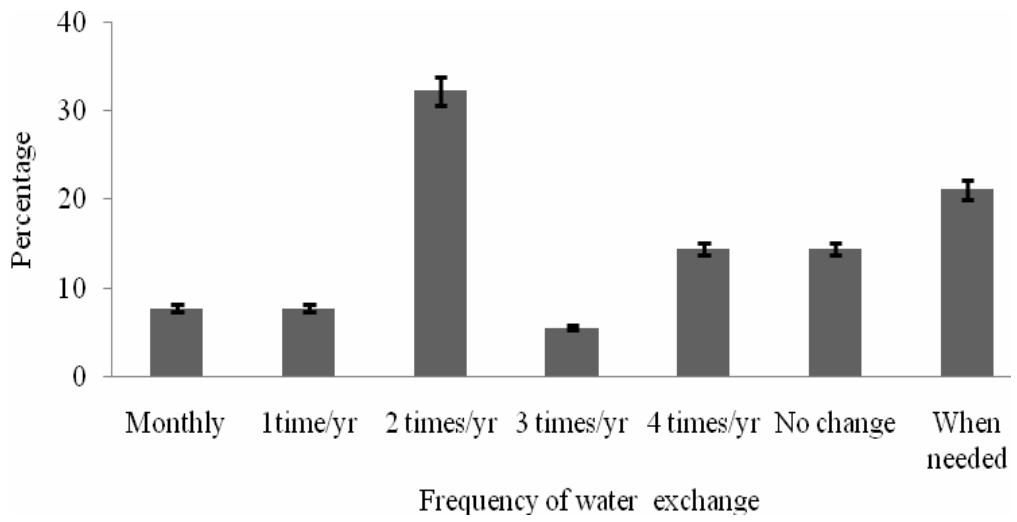

Fig. 7. Frequency of water exchange in pangas farms

The environmental concern due to unconscious or unplanned aquaculture practices has also been observed through discharged farm water and effluents in the present study. Effluent from semi-intensive or intensive pangas farms are of major concern as a source of pollution to natural waters. Nearby agricultural lands were mostly $(73.33 \%)$ used by pangas farmers to discharge pond water and some of the pangas farmers $(11.11 \%)$ have no scope to discharge water from their ponds (Fig. 8). Though farmers were not found to discharge water after proper treatment at all, no complain was reported by the receivers of this water in their land. The highly nutrient rich pond water was reported well for rice production. Ali and Haque (2011) found the same trend that discharged wastewater of Pangasius pond increased rice productivity in adjacent agriculture farm by $10 \%$ and additionally reduced fertilizer and irrigation cost by $30 \%$ and $40 \%$, respectively.

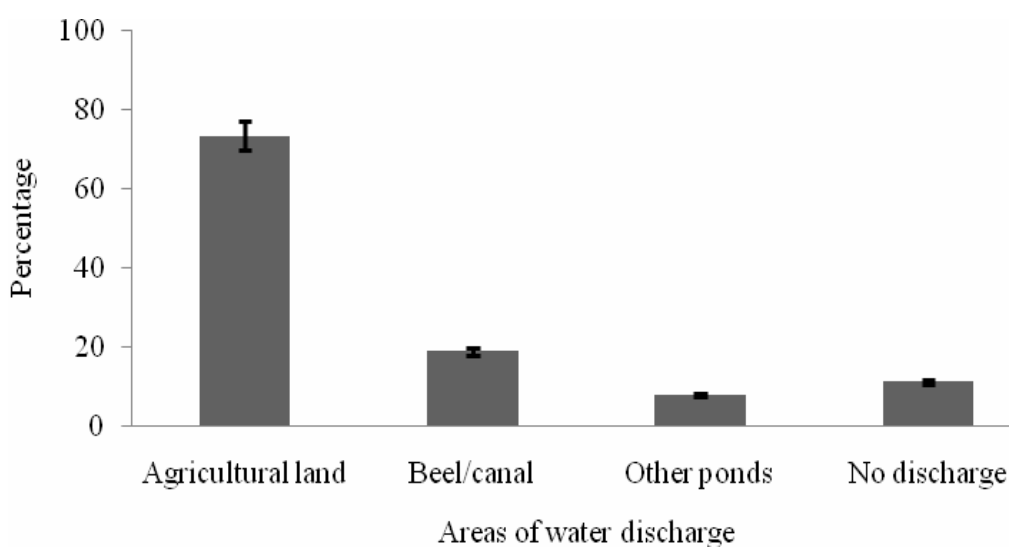

Fig. 8. Discharge of water from the ponds 


\section{Eutrophication}

The nutrient rich water created by excess feeds enhanced the productivity of agricultural land. However, some user of this nutrient water reported that due to high productivity the paddy grows very quickly. There was also concern about off-flavour in the flesh of fish due to unconscious feed selection for farmed pangas in commercial ponds of survey area of interests. All the interviewed farmers told about the eutrophication problem in their farms due to algal bloom. Due to decomposition of dead algae different types of harmful gases were produced which created stressful condition for cultured species. In some cases eutrophication resulted mortality of fish. Production of algal blooms in fertile pangas ponds was also reported by Belton et al. (2011).

\section{Waste disposal and management}

Sediment depositions on the pond bottom in the present study has resulted water quality deterioration and reduced growth of fish. Pangas farms were generally found reluctant to remove this sediment regularly due to higher labor cost and unavailability of place to dump. Farmers were found to remove their pond bottom waste in every two years. Some farms were too large to remove bottom waste. This waste caused the production of different harmful gases and oxygen depletion in the pond. All farmers used to removed their pond bottom waste and dry their culture ponds after certain period of time. Overall average $43.33 \%$ farmers disposed their pond bottom waste in every two years followed by $33.33 \%$ in every three years and $16.67 \%$ farmers in every four years. A few farmers $(6.67 \%)$ were found to manage their farm wastes yearly (Fig. 9). Some farms were so big that it was not possible to remove bottom waste at all or discharge pond water (Fig. 10).

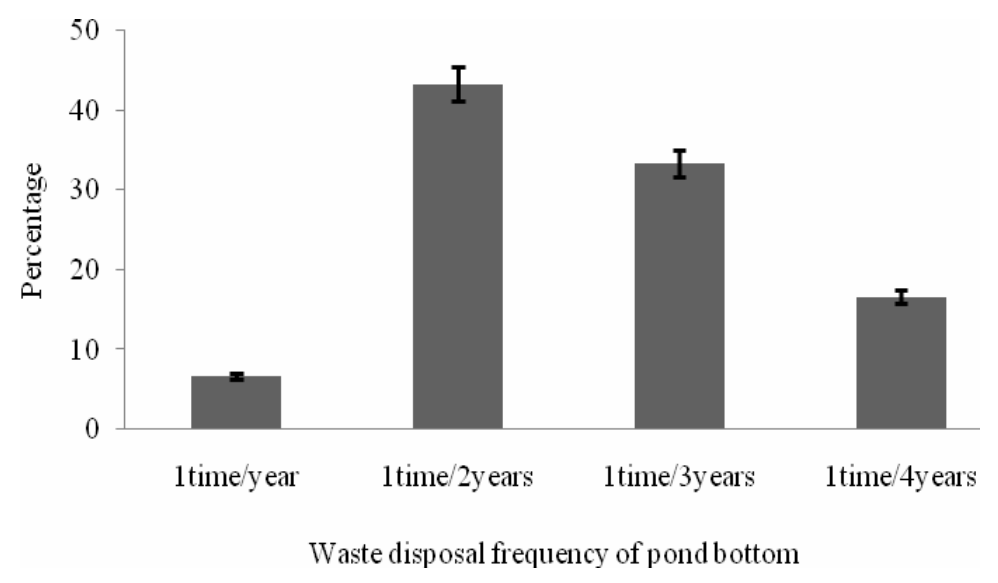

Fig. 9. Waste disposal frequently maintained by pangas farmers

The huge amount of bottom decomposed mud sometimes is responsible for creating offflavor. This waste caused the production of different harmful gases which resulted oxygen depletion in the pond. Because of not removing waste yearly, growth of fish was reduced and fish became susceptible to disease. Some respondents opined that after 3 year's pangas pond becomes totally unsuitable for culture if waste remains unresolved. Bottom waste was used by some farmers for cropping in nearby area of pangas ponds in the present study. In 
a recent study, Monira (2012) observed that pangas pond sediment had the high potential to grow vegetable with better production without any manure and chemical fertilizer. Aquaculture indirectly benefits the environment by providing a method to convert agriculture waste into high-quality fish protein through enriching pond mud for improving soil quality by functioning as fertilizer on crop land (Muir, 1999). Some farmers reported good dyke crop production using pond bottom wastes in the present study. Boyd (1995) stated that pond sediment is not only source of nutrient but also have biological filtering ability. Farmers told that, pangas ponds could be turned into nutrient explosion if bottom waste remained accumulated with no removal for two to three years. Waste was also used in the brickfield.

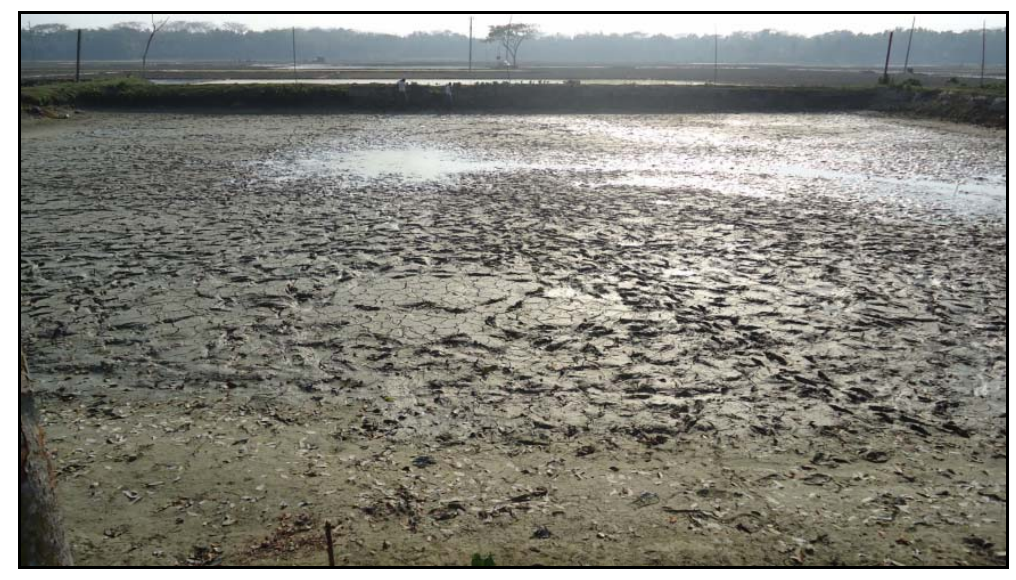

Fig. 10. Pangas pond bottom waste

\section{Use of chemicals and antibiotics}

Most farmers $(85.56 \%)$ used different types of chemicals and antibiotics to control disease (Table 4). Chemicals used in aquaculture can cause pollution in the environment. These chemicals can come from antibiotics, pesticides, herbicides, hormones, anesthetics, pigments, minerals, and vitamins (Goldberg et al., 2001; JSA, 2007).

Table 4. Use of antibiotics

\begin{tabular}{|c|c|c|c|c|}
\hline Criteria & $\begin{array}{c}\text { Muktagacha }(\%) \\
n=10\end{array}$ & $\begin{array}{c}\text { Trishal }(\%) \\
\mathrm{n}=15\end{array}$ & $\begin{array}{c}\text { Valuka }(\%) \\
\mathrm{n}=15\end{array}$ & Average (\%) \\
\hline Yes & 70 & 86.67 & 100 & 85.56 \\
\hline No & 30 & 13.33 & 0 & 14.44 \\
\hline
\end{tabular}

Farm workers were seen to handle antibiotic and chemicals without any protection that might cause their health problem (Fig. 11).

It has been reported in the present study that, farmers apply drugs by their own sense rather than suggestions of experts. About $80 \%$ farmer does not go to extension officer for advice and they were found to apply a range of treatments indiscriminately for disease 
control without knowing their effect (Faruk, 2008). A concern about antibiotic use is that it may affect unintended species leading to antibiotic resistance including other toxic effects (Brown, 1989). Chemicals were used by the farmers here and there unconsciously and traditionally in the present study. Farmers were found to handle the drugs and chemicals for disease treatment or prevention without any protection. David et al. (2009) stated that there are health risks to workers associated with microbial exposure and processes related to the prevention of infectious diseases in aquaculture species and aquaculture workers can be exposed to uncommon microbes including bacteria, viruses, algae, and parasites potentially causing zoonotic disease or emerging infections. This would be responsible for antibiotic resistance that could be exposed as a major environmental impact. In the present study, it was observed that farmers did not well-known about the existing and future environmental concerns due to this irrational treatment measures. They were not also aware of handling the diseased fish that might be contagious to them in present study.

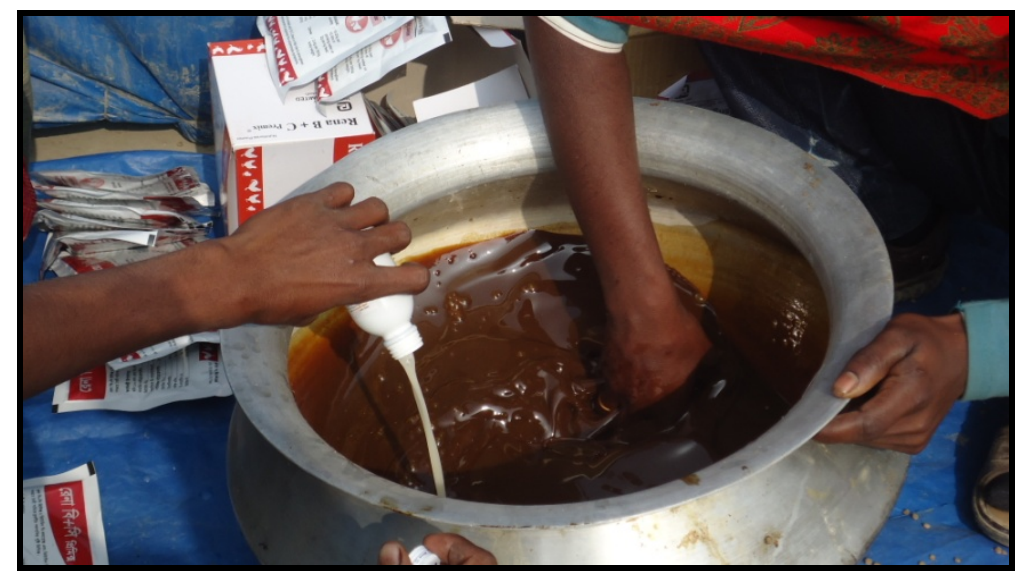

Fig. 11. Antibiotic handling by farm worker having no precaution

\section{Escape of fish}

Pangas was reported as well domesticated fish and no farmed pangas or cross breed pangas were found in the adjacent river in the present study. Similar fact was also reported by Edwards and Hossain (2010) where the ponds have low dykes and so many floods during the monsoon season, but the striped catfish, pangas unlike other farmed species, remain in flooded ponds. No farmed pangas or cross breed pangas were found in the adjacent river as was reported by fishermen and farmers.

\section{Activities of birds}

Kite birds and Water fowls were found in numbers around pangas pond to prey juvenile fish. This could help them to survive. However, it could be a potential reason of losing fish by farmers. According to Pillay (1992), a pelican can consume between 1 and 3 tones of fish per year and herons may cause losses up to $30-40 \%$ of fry and juvenile fish per year. Moreover, these birds could act as mechanical carrier of disease to other farms. In order to 
protect fish from bird farmers used small ball and stick to hunt birds. They were found to employ professional tribal people to do this activity.

\section{CONCLUSION}

Pangas farming with the rapid expansation and intesification, have raised environmental problems as a great concern in recent years. The mitigation of all the negative aspects is also essential for ensuring the better culture practices. It is essential to create awareness among pangas farmers about environment to develop their skills to mitigate such problems for sustainable pangas farming of Bangladesh. Further research work is needed for more specification of the causes of the identified problems.

\section{ACKNODLEDGEMENT}

The research was supported by the Bangladesh Agricultural University Research System (BAURES) which is greatly acknowledged.

\section{REFERENCES}

Ali, H. and Haque M. M. 2011. Impacts of Pangasius Aquaculture on Land Use Patterns in Mymensingh District of Bangladesh. J. Bangladesh Agril. Uni., 9(1): 169-178.

Belton, B., Haque, M. M., Little, D. C. and Sinth, L. X. 2011. Certifying Catfish in Vietnam and Bangladesh: Who will make grade and will it matter? Food Policy., 36: 289-299.

Belton, B., Little, D. C. and Sinh, L. X. 2011. The Social Relations of Catfish Production in Vietnam. Geoforum., 42: 567-577.

Boyd, C. E. 1995. Bottom Soils, Sediment and Pond Aquaculture. Chapman and Hall, New York. $348 \mathrm{p}$.

Brown, J. H. 1989. Antibiotics: their use and abuse in aquaculture. World Aquaculture., 20: 34-43.

David, W.C., Richard, C., Steven, J. G. , Jon, G., Greg, H., Mark, L. J., Nicole, P. D., Charu, S. and William, W. 2009. Aquaculture: Environmental, toxicological, and health issues. Int. J. Hyg. Env. Health., 212: 369-377.

Edwards, P. and Hossain, M. S. 2010. Bangladesh Seeks Export Markets for Striped Catfish. Global Aquaculture Advocate, May/June 2010.

FAO . 2010. Cultured Aquatic Species Information Programme: Pangasius hypophthalmus. Food and Agricultural Organizations of the United Nations, Rome, Italy.

Faruk, M. A. R. 2008. Disease and Health Management of Farmed Exotic Catfish Panagasius hypopthalmus in Mymensingh District of Bangladesh, Dis. Asian Aquacul., 16: 193-204.

Goldberg, R. J., Elliott, M. S. and Naylor, R. L. 2001. Marine Aquaculture in the United States: Environmental Impacts and Policy Options. Pew Oceans Commission, Arlington, Virginia.

Haque, M. M. 2009. Emerging Pangasius Aquaculture Dialogue (PAD) Standards: Can Bangladesh Comply with? Paper Presented in Pangasius Aquaculture Dialogue (PAD) Meeting, 22 Aug 2009, Bangladesh Agricultural University, Mymensingh. 
JSA (Federal Joint Subcommittee on Aquaculture). 2007. Working group on quality assurance in aquaculture production: guide to drug, vaccine, and pesticide use in aquaculture, April 2007 revision. http://aquanic.org/jsa/wgqaap/dru gguide/Drug\%20Guide\%207-5-07.pdfS (accessed on 20 October, 2007).

Monira, S. M. 2012. Potential for Use of Pangasius Pond Sediment in Roof Top Bag Gardening: A Broader Integrated Aquaculture-horticulture Approach. M. S. ThesiS, Department of Aquaculture, Bangladesh Agricultural University, Mymensingh, Bangladesh.

Muir, J. 1999. The Solution to Pollution? The Value and Limitations of Environmental Economics in Guiding Aquaculture Development. Aquacul. Econ. Management., 3: 43-57.

Pillay, T. V. R. 1992. Aquaculture and the Environment. Fishing News Books, Cambridge, USA. 6-95 p.

World Fish Center. 2011. Bangladesh Fisheries Review: Input towards IFAD's Bangladesh COSOP. Dhaka: World Fish Center. 